\title{
Dansk udenrigspolitisk aktivisme i nyt farvand?
}

Rasmus Brun Pedersen

\section{Det liberale moment i international politik er endnu ikke helt passé, og det betyder, at Danmark får nye muligheder for alliancer som udenrigs- tjenesten skal være bedre til at håndtere}

Det danske udenrigsministerium har netop publiceret et debatoplæg Kurs mod 2020 - Dansk udenrigspolitik $i$ nyt farvand. Heri præsenteres en analyse af rammevilkårene og visionerne for den danske udenrigspolitik hen imod år 2020 (Udenrigsministeriet 2010). Oplægget kan tolkes som udenrigsministeriets seneste bud på, hvilken vej den danske udenrigspolitiske aktivisme bør bevæge sig i. Oplægget fremstår derfor på en række områder som en central analyse af rammevilkårene for dansk udenrigspolitik og deres relevans for indholdet i den udenrigspolitiske strategi de kommende år.

Udenrigspolitisk aktivisme har siden den kolde krigs afslutning været strømpilen for dansk udenrigspolitik, som i denne periode har været gearet til at skulle gøre op med den traditionelt mere tilbageholdende og balancerende karakter i den danske udenrigspolitik. Aktivismen i dansk udenrigspolitik er imidlertid langt fra en entydig størrelse og har fra den kolde krigs afslutning gennemgået en række udviklingsfaser. Fra i 1990'erne at have haft en multilateral karakter med vægt på multilateral aktivisme igennem $\mathrm{FN}, \mathrm{EU}$ og andre internationale alliancemedlemskaber udviklede aktivismen sig igennem 2000-tallet i en mere atlantisk orienteret retning, hvor tyngden i udenrigs- og sikkerhedspolitikken lå i prioriteringen af et mere snævert samarbejde med USA gennem etableringen af fleksible koalitioner (Pedersen 2011). Et andet kendetegn var en prioritering af liberale værdier som det styrende princip for dansk udenrigspolitik.

Udenrigsministeriets seneste oplæg om perspektiverne for dansk 
udenrigspolitik er interessant ved, at det på en række områder markerer et brud med Fogh-æraens danske aktivisme og derved en (forsigtig) distancering fra dennes betoning af den atlantiske søjle i den danske udenrigspolitik. Pointen i oplægget er relevansen af magtspredning og af Kina og de øvrige BRIK-landes stigende globale betydning. Ligeledes peger oplægget på, at spredningen til demokratiske 'anden-bølge lande' så som Indonesien, Vietnam mv. skaber nye forudsætninger.

Oplægget markerer, at fremtiden for dansk udenrigspolitik synes at ligge i en tilbagevenden til et mere traditionelt multilateralt spor for den danske aktivisme. Et spor vi så praktiseret i den engagerede internationalisme gennem 1990'erne. Oplægget markerer derved en første forsigtig tilbagetrækning fra Foghs praksis med international aktivisme (Udenrigsministeriet 2003).

\section{Aktivismens udgangspunkt}

Oplægget er interessant ved, at det er med til at fremtidssikre aktivismen som ledetråd for den danske udenrigspolitik. Derved vil oplægget formentlig kunne adopteres af en eventuelt kommende socialdemokratisk ledet regering, da indholdet på en række områder ligger tæt på de tanker og ideer, som partiet har præsenteret (fx Socialdemokraterne 2006). Dette drejer sig særligt om analysen af ændringerne i de over- ordnede rammer for den danske udenrigspolitik og betydningen af multilaterale platforme som operatør for dansk udenrigspolitik.

Da den danske udenrigskommission i 1990 præsenterede sit udkast til en ny dansk udenrigspolitisk strategi efter den kolde krigs afslutning, blev rapporten indledt med citat fra Shakespeares tragedie Julius Cæsar. Citatet henviser til, hvordan de sammensvorne i tragedien skulle benytte momentet til at afkaste Cæsars diktatordrømme og genrejse republikken. Med andre ord skulle man gribe og udnytte øjeblikkets mulighed til at skabe forandring i den romerske republik og frelse den fra diktatorisk tyranni og sikre demokratiets (republikkens) orden og retfærdighed.

I en mere nutidig tolkning refererede kommissionens betænkning til, at Danmark som småstat efter murens fald skulle gribe det opståede $l i$ berale moment til en ændring af sin udenrigspolitik (Fukuyama 1992; Udenrigskommissionen 1990). Murens fald betød en ændring i de ydre rammebetingelser for den danske udenrigspolitik - ja ligefrem et liberalt og demokratisk højvande, som krævede nye offensive danske svar. Derved var der lagt i ovnen til et historisk sceneskifte i dansk udenrigspolitik.

Det svar, som det danske udenrigsministerium formulerede, og som vandt bred parlamentarisk støtte, indeholdt den første forsigtige formu- 
lering af, hvad der har været betegnet som en mindre revolution $\mathrm{i}$ dansk udenrigspolitik, nemlig formuleringen af en dansk udenrigspolitisk aktivisme. Aktivisme henviser i denne sammenhæng til en ambition om at føre en aktiv udenrigspolitik eller muligheden for at aktivere sine udenrigspolitiske kapaciteter gennem deltagelse eller medvirken i internationale organisationer eller at forfølge selvstændige udenrigspolitiske ambitioner (jf. Pedersen 2011). Dette betød med andre ord en opgivelse af den tilbageholdende danske udenrigspolitik, som i sin kerne søgte at undgå en for forpligtende aktivering gennem sine internationale alliancemedlemskaber, og som snarere søgte at fokusere på balancering og mediering mellem polerne under den kolde krig.

Ambitionen var at udnytte det liberale moment og derved søge at geare den danske udenrigstjeneste til at agere mere aktivt internationalt og sigte på en stigende grad af dansk involvering i genopbyggelsen af en europæisk sikkerhedsarkitektur via etablering og udbygning af internationale organisationer. Målsætningen var at skabe rammen for etableringen af en 'liberal ordenspolitik' i multilaterale rammer, hvori Danmark skulle indtage en central placering (jf. Petersen 2010). Målsætningen var at regulere de internationale relationer via internationale organisationer for derved at reducere den farlige magtpolitiks betydning.
På trods af tilbageslaget i forbindelse med den danske ratificering af Maastricht-traktaten har den aktivistiske vision for dansk udenrigspolitik vist sig både succesfuld og overlevelsesdygtig. Succesfuld fordi den har været med til at placere Danmark centralt blandt de sikkerhedspolitiske aktører i de alliancer, som Danmark har deltaget i. Overlevelsesdygtig fordi den har opnået bred politisk opbakning, og har været i stand til at samle det traditionelle sikkerhedspolitiske flertal bag dansk udenrigs- og sikkerhedspolitik. I hvert fald indtil 2001.

\section{Brud eller kontinuitet?}

Mens formuleringen af aktivismen i starten af 1990'erne kunne henføres til murens fald og ønsket om at udnytte de gunstige vilkår til at føre en aktivistisk udenrigspolitik, ikke mindst i det baltiske område, har de nødvendige forudsætninger herfor i praksis altid ligget i et dansk samarbejde med USA. Denne amerikanske tilknytning blev særligt betonet efter 11. september og det danske valg i 2001, hvor den liberalt-borgerlige regering overtog regeringsmagten og for første gang i over 70 år havde et flertal uden om det Radikale Venstre og Socialdemokraterne på det udenrigspolitiske område.

Den nye regering benyttede momentet til at betone den atlantiske søjle og prioriterede derved en snæver alliance med USA i forhold til 
deltagelsen i de to koalitionskrige i Afghanistan og Irak (Pedersen 2011). Tilslutningen til disse to krige markerede en forskydning i tyngden af den danske udenrigspolitik, som indenrigspolitisk ikke gik stille for sig. Ændringen var med til at slå skår i billedet af strategiens overlevelsesevne, da det brede sikkerhedspolitiske flertal blev slået itu i perioden 2002-2003 (Holm 2002; Rynning 2006). Bruddet betød, at liberal værdipolitik blev introduceret som en samlende ramme for den danske udenrigspolitik (Udenrigsministeriet 2003). Ligeledes kom der yderligere fokus på udviklingen af militær interventionskapacitet. De ændrede ydre rammer og den interne tyngdeforskydelse ledte til en række ændringer i dansk udenrigspolitik, som betød, at de borgerlige regeringers udenrigspolitik i perioden fra 2001-2010 fik en militariseret karakter og en langt mere fremtrædende rolle i den indenrigspolitiske debat (Petersen 2006).

En af konsekvenserne af denne atlantisk orienterede aktivisme, med sit fokus på dansk deltagelse i fleksible ad hoc baserede koalitioner, blev en svækket Europa-politik. 1990'ernes klare borgerlige afstandtagen til EU-forbeholdene af 1992 blev afløst af en mere pragmatisk holdning, der bestod i en bevidst fastholden af centrale dele af det retlige forbehold og en udsættelse af stillingtagen til de øvrige dele af forbeholdene, ligesom regeringens politikere ved flere lejligheder fremførte kritiske FN- og EU-røster.

Spørgsmålet er, om denne vægtning kan fortsætte, og om strategien også i fremtiden er holdbar. Formuleringen af det seneste forsvarsforlig markerede, at politikerne fortsat prioriterer en international dansk interventionskapacitet, ligesom partierne bag forsvarsforliget i sommeren 2009 tilsluttede sig Forsvarskommissionens konklusion om, at efterspørgslen efter danske militære bidrag ikke vil mindskes, og at det nuværende ambitionsniveau for forsvarets evne til at bidrage internationalt bør fastholdes. Dette taler for en fortsættelse af Fogh-æraens offensive aktivistiske udenrigs- og sikkerhedspolitik.

Der eksisterer også en række begrænsninger. Foghs afsked med dansk politik har betydet, at den primære centrale drivkraft har forladt dansk politik. Internationalt har Barack Obama på kort sigt ganske vist signaleret en opprioritering af indsatsen i Afghanistan, men et fremtidigt exit er dog stadigt det mest sandsynlige. Derved synes en del af de indre og ydre betingelser for at fastholde en international aktivisme at være bortfaldet.

USA fremstår i dag fortsat som verdens supermagt, men position og status er truet af en række af de nye asiatiske magter med Kina i spidsen, ligesom kredsen af øvrige BRIK-lande også lægger pres på USA's globale dominans. Samtidig synes den 
$\varnothing$ konomiske afmatning at have taget dampen af den amerikanske maskine.

Man må derfor forvente en mere indadvendt amerikansk politik de kommende år, som ikke mindst vil fokusere på at få genoprettet økonomien, ligesom den vil antage en måske mere forsigtig balancerende strategi over for de nye magter, som er ved at gøre deres entre på den internationale scene. Disse ændringer vil få konsekvenser for prioriteringerne og målsætningen i den danske aktivisme, da en af de nødvendige forudsætninger for Fogh-regeringernes højtprofilerede udenrigspolitiske strategi har været muligheden for tilslutning til den amerikanske udenrigspolitik.

\section{Imod 2020 - Quo vadis?}

Ændringerne i de eksterne forudsætninger for dansk udenrigspolitik synes at varsle en tilpasning af den danske udenrigspolitiske strategi for at sikre, at Danmark fortsat kan manøvrerer internationalt.

Udenrigsministeriets giver en nøgtern analyse af perspektiverne for dansk udenrigspolitik, herunder ikke mindst betydningen af de ændrede rammevilkår for på hvilke områder Danmark skal prioritere sin udenrigspolitik. Analysen peger især på relevansen af en øget international magtspredning, der sammen med den økonomiske krise har medført ændringer i den internatio- nale magtbalance til fordel for især Kina og de øvrige BRIK-lande. Analysen rummer herved et første og forsigtigt opgør med Fogh-æraens relative vægtning af den atlantiske komponent til fordel for en ny global virkelighed med en begrænset global amerikansk dominans. Begrundelsen rummer tre forhold:

1) En forskydning i det internationale verdenskort, som Danmark tidligere har navigeret efter, hvor den magtpolitiske tyngde rykker væk fra USA og i retning af Kina og de øvrige BRIK-lande. Det betyder flere stærke aktører på den internationale scene.

2) For det andet fastslår analysen, at magtspredningen er en realitet, hvilket logisk afgørende ændrer rammevilkårene for dansk udenrigspolitik, der siden 2001 har været fokuseret på udfoldelsen af international aktivisme i en unipolær struktur.

3) Endelig skal Danmark fastholde et uændret ambitionsniveau i sin udenrigspolitik. Det betyder konkret, at man ønsker at fastholde aktivismen i dansk udenrigspolitik, ligesom man ønsker at fastholde værdipolitikken som styrende princip for den danske indsats. Dog må indsatsområder og den relative vægtning af de forskellige hjørnestene justeres, ligesom midlerne i udenrigspolitikken må målrettes i takt med de ændrede rammevilkår.

En af de centrale pointer er, at den nye globale situation også rummer en række muligheder for Dan- 
mark og Vesten, da en række af de nye rising powers deler en række centrale karakteristika, nemlig at der for de flestes vedkommende er tale om demokratier med demokratiske idealer og værdier. Der er således stadig et vist demokratisk højvande i det internationale system, og det liberale moment $\mathrm{i}$ international politik synes derved ikke helt passé endnu. Det betyder at Danmark får nye muligheder for alliancer, som udenrigstjenesten skal være bedre til at håndtere i det globale spil gennem prioriteringen af de multilaterale arenaer i verdenspolitikken. Konkret betyder dette en opprioritering af $\mathrm{FN}$-systemet i et forsøg på at regulere og kontrollere magtspredningen og bringe den ind i regulerede multilaterale baner ved at etablere en global ordenspolitik baseret på liberale præmisser.

På det regionale plan synes oplægget at genopdage EU som en central platform for udførelsen af dansk udenrigspolitik. Ikke forstået sådan at EU ikke var en relevant komponent i den tidligere udenrigspolitik under Fogh, men betoningen og vægtningen - ikke mindst på grund af den fejlslagne ratificering af Forfatningstraktaten og de konstitutionelle debatter, som prægede 2000'erne - var med til at lægge EU-strategien i mølposen og rette fokus på den atlantiske komponent. De danske muligheder i EU-samarbejdet underst $\varnothing t$ tes i oplægget særligt af iagttagelsen af, at Lissabon-traktaten har forsynet EU's udenrigstjeneste med en bred værktøjskasse, som gerne skulle udvikles og bruges de kommende år. Konkret skal værktøjerne bruges til at skabe sammenhæng mellem EU's politikker og styrke EU udadtil, ligesom EU skal have sæde i FN-systemet.

Oplægget indeholder ikke en betingelsesløs omfavnelse af EU som genfunden arena for dansk udenrigspolitik, da EU's nye udenrigstjeneste fortsat har brug for at bevise, at den kan agere internationalt. Dette retter selvsagt fokus på nødvendigheden af at afskaffe de danske forbehold for at sikre Danmark en mere central position i EU's udenrigspolitiske arbejde.

Oplægget synes at rumme et opgør med den danske udenrigspolitik fra 2001-2010 og dens betoning af aktivisme med stærk atlantisk tilknytning. Den generelle krigsafvikling i Afghanistan samt betoningen af den økonomiske krise og vægtningen af den globale magtspredning tolkes som nye rammevilkår for Danmark, hvilket betyder en flytning af den relative vægt fra den atlantiske til den globale og den europæiske søjle i dansk udenrigspolitik.

Under overskriften 'værdier samme mål, nye midler' sammenfatter oplægget kernen i fremtidens udenrigspolitik. Værdibaseret politik fremstår tilsyneladende som den centrale pointe i oplægget, men den skal ikke længere praktiseres gennem en aktiv indsats i ad hoc lignen- 
de alliancer, men i stedet i multilaterale fora. På dette punkt konsoliderer oplægget dog en af de centrale pointer fra Fogh-æraen, nemlig et værdibaseret udgangspunkt for den udenrigspolitiske aktivisme. Mens det har været naturligt at snakke om værdipolitik for de borgerlig-liberale regeringer, er det også gradvist blevet det for det Radikale Venstre, Socialdemokratiet og Socialistisk Folkeparti, der alle i en vis udstrækning har accepteret værdipolitikken som en samlende målsætning for dansk udenrigspolitik.

\section{Gammel vin på nye flasker}

Derved er vi tilbage ved Shakespeare-citatet om at gribe øjeblikkets mulighed. Ændrede rammevilkår og en vækst $i$ antallet af nye demokratiske lande betyder et behov for at revidere hvilke midler og strategier, der skal anvendes i dansk udenrigspolitik. Ministeriet genopfinder på en række områder den aktivistiske internationalisme, som blev formuleret under tidligere udenrigsminister Uffe Ellemann-Jensen, og som blev praktiseret under skiftende socialdemokratisk ledede regeringer frem til 2001. Analysens konklusioner er givet vis godt nyt for de mange, der har påpeget, at udenrigspolitikken under Fogh-regeringerne afspejlede en for Danmark unaturlig offensiv politik, der tilsidesatte de internationale organisationer og prioriteringen af multilaterale platformes betydning for dansk udenrigspolitik, herunder ikke mindst hensynet til opbygningen af en international ordenspolitik. Dansk udenrigspolitik skal ifølge oplægget tilbage til sit multilaterale udgangspunkt og fokusere på at opbygge og bevare en international (liberal) orden, der er reguleret af internationale organisationer og international ret, ved at udnytte det demokratiske højvande til at søsætte en liberal ordenspolitik.

Oplægget synes samtidig at rumme en anden (indenrigspolitisk) kvalitet, da det er med til at fremtidssikre en bred enighed bag dansk udenrigspolitik ved netop at lægge Foghs visioner om international aktivisme fra sig. Dette hænger sammen med, at Socialdemokraterne, det Radikale Venstre og Socialistisk Folkeparti formentligt ikke vil have problemer med overtage og forvalte visionerne i oplægget i tilfælde af et regeringsskifte, hvormed rammerne for et fremtidigt bredt funderet samarbejde om udenrigspolitikken synes sikret.

Rasmus Brun Pedersen er Adjunkt, ph.d., Institut for Statskundskab, Aarhus Universitet

Litteraturlisten kan rekvireres ved at sende en mail til brita@udenrigs.dk 